\title{
Problems Faced by Catholic Partners in Inter-religious Marriage in Flores, South-east Indonesia
}

\author{
Yohanes S. Lon \\ Universitas Katolik Indonesia Santu Paulus Ruteng
}

\begin{abstract}
This article highlights the problems experienced by catholic couples married to non-Catholic couples in Flores, Southeast Indonesia. Through the literature and field approaches, this study found that many catholic couples experienced double forms of the marriage celebration, difficulties in marriage legality and children's education, and failure in building harmony and resilience of the integrity of their marriage. This article emphasizes the problems due to the absence of explicitly mentioning interfaith marriage in the articles of Law No.1 of 1974 concerning Marriage. Marriage Law should be made friendly to religious diversity and interfaith Marriage in Indonesia. Interfaith/ interreligious marriages in Indonesia should receive adequate legal, religious, and social protections. Furthermore, married couples who live in interfaith marriages must develop an inclusive religious mindset and practical interpersonal communicative skills to make their marriage permanent.
\end{abstract}

Keywords: Mixed Marriage, Catholic, Interreligious, Flores

\section{Introduction}

Indonesia is a plural society consisting of various ethnicities, religions, races, and groups. More than a thousand tribes and a thousand languages spread over 17000 islands in the archipelago. In addition to the six world religions that are officially recognized by the state as recorded in the decision of the Constitutional Court of the Republic of Indonesia No. 97 / PUUXIV / 2016 dated October 18, 2017 (namely Islam, Christianity, Catholicism, Hinduism, Buddhism, and Confucianism), there are many ancestral religions of the local community. The various cultures are very much reflected in the types of dances, types of songs, types of music, and other arts that stretch from Aceh to Merauke. In terms of race, the people consist of the Mongoloid race (such as in Java, Sumatra, Kalimantan, Sulawesi) and the Melanosoid race (Eastern Indonesia).

In a pluralistic society, the interaction between people from different tribes, religions, races, and groups is widespread, and therefore mixed marriages between people of different ethnicities, races, religions, and groups are unavoidable. Studies conducted by Sri Wahyuni (Sri Wahyuni, 2010) (Sri Wahyuni, 2018) and Indrayanti Kadek et al. (Indrayanti, 2017) confirm that interfaith (interreligious) marriages still frequently occur in Indonesia. In the 1970s, there were recorded interfaith marriages between Emelia Contessa (Islam) and Rio Tambunan (Christian), and in the 80s, between Jamal Mirdad, a Muslim, and Lydia Kandau, a Christian artist.

In addition, different nationality marriages were recorded, for example, marriages between Bunga Citra Lestari and Asraf Sinclair and Krisdayanti and Raul Lemos (Aini, 2008) (Husain Insawan, 2008). The highest number of mixed interfaith marriages occurs between Muslim and 
Protestant, followed by those who are Muslim and Catholic, Muslim and Hindu, Muslim and Buddhist (Indrayanti, 2017).

During the Dutch East Indies period, the Government issued a Decree of the King on December 29, 1896, no (Stb.1898 No 158), which was called the regulation on mixed Marriage (Regeling op de Gemengde Huwelijken) and was known as GHR. According to this decree, interfaith marriages will be recorded by the civil registry office. However, when Indonesia became independent, Law No. 1 of 1974 on Marriage no longer explicitly states interfaith (interreligious) marriage in its articles. Article 57 only talks about mixed nationality marriages.

So, when Article 2 states that legal marriages must be carried out according to the laws of religion and belief, this rule implicitly prohibits interfaith marriages. However, this interpretation is different from Law no. 23 of 2006 regarding Population Administration, Article 35 letter a, which provides opportunities for those going to marry interfaith marriages. From the two laws and regulations, there are conflicts with one another. According to the 1974 Marriage Law, interfaith marriages are prohibited but based on the 2006 Population Administration Law, interfaith marriages are allowed. This difference can be interpreted as a legal uncertainty or legal vacuum (Supriadi, 2020) (Lon, 2019b) (Sri Wahyuni, 2018).

Debates and ambiguity about interfaith marriages also occur in various religions in Indonesia. The prohibition of marriage between people of different religions is often based on a belief in the existential truth of their religion. Every religion believes that its religion is the truest, and every adherent is obliged to defend, defend and spread the truth. This belief gives birth to a prohibition for people from other religions to marry. Furthermore, the prohibition of interfaith marriage is driven by the belief like marriage is a community of life that covers all its aspects and dimensions: personal-social, spiritual-physical. Marriage demands an exclusive physical, emotional, spiritual union. It is difficult to imagine a total unity without the heart's desire and unity of faith from the two partners (Lon, 2019a)

In Islam, some groups reject interfaith marriages based on Al Baqarah (2): 221 and Article 44 of the Compilation of Islamic Law, which emphasizes the prohibition for Muslim women to marry men who are not Muslim. In fact, on June 1, 1980, the Indonesian Ulema Council (MUI) issued a fatwa prohibiting Marriage between Muslim men and non-Muslim women, including women ahl al-Kitāb, and vice versa. MUI Fatwa Decree No. 4 / MUNAS VII / MUI / 8/2005 concerning Marriages with Different Religions stipulates fatwas on Marriages with Different Religions, namely: 1) Interfaith marriages are haram and illegitimate; 2) Marriage between a Muslim man and a woman ahl al-Kitāb is haram and illegitimate. However, some groups argue that Muslims are allowed to marry non-Muslims by quoting Al Maidah verse 5 (Sri Wahyuni, 2016) (Supriadi, 2020) which states that Muslim men can marry women who are ahlul of the book and their views on equality and marriage. Two daughters of the Prophet from Siti Khadijah: Rukayyah and Zainab were married to non-Muslim men.

The debate about interfaith marriage also exists in Christianity. Some churches allow mixed interfaith marriages because an unbelieving couple is sanctified by a husband or wife who has faith. This openness has happened to significant figures in the Bible such as Joseph, Moses, Esau, Simeon, and Judah (cf. Gen. 38, 1-2; 46, 10; 41,45; Num. 12, 1). However, some churches prohibit it and even exclude church members married to people of no religion from their membership. This view is inspired and based on the biblical text of 2 Cor. 6:14, which reads, "Do not be unequal with unbelievers. For what similarities exist between righteousness and iniquity? Alternatively, how can light be united with dark (Munir, 2011) (Makalew, 2013).

In Buddhism, Marriage between fellow Buddhists is highly recommended. The purpose of marriage is to achieve the happiness of husband and wife. According to Buddhist teachings, the happiness of husband and wife presupposes the existence of a) equal sada (same belief), b) same 
sila (same morality), c) equal caga (same generosity), and equal pasiya (same wisdom). Indeed, there is no strict prohibition for followers of marriage with followers of other religions. However, if such a marriage occurs, the marriage must be carried out according to Buddhist religious procedures. Non-Buddhist couples are required to make their marriage vows in the name of Buddha, Dharma, and Sangha. The pronunciation can be interpreted that implicitly the person concerned has become a Buddhist. This, of course, is burdensome for non-Buddhist parties (Sri Wahyuni, 2016) (Makalew, 2013) (Sri Wahyuni, 2010).

In Hinduism, there is a teaching on samkara which emphasizes the principal requirements for the validity of the marriage. First, men and women who want to get married must already be in one religion, namely Hinduism. Second, widiwadana, namely marriage inauguration led by sulinggih or panindita. Thus, in principle, interfaith marriage is prohibited. Every bride and groom who is not a Hindu is obliged to marry as a Hindu. Any marriage that does not meet the two requirements above is invalid (Makalew, 2013).

This paper will explore the various problems experienced by Catholic couples when they have interfaith marriages and the views of Catholicism on mixed interfaith marriages. What are the rules of the Catholic Church regarding mixed interfaith marriages, especially between Catholics and Muslims? How does the Catholic Church accommodate the right of its people to marry people of other religions? How is the experience of a Catholic couple who married a couple of other religions? Studies like this have been conducted by G.P. Sepang (Gledys Patrisia Sepan, 2015), who made a legal review of interfaith marriage based on the Book of Canon Law and Law No. 1 of 1974 on marriage, and Abdi Pujiasih (Pujiasih, 2008), who reviewed the views of Islam and Catholicism on interfaith marriage. In contrast to the two studies, the focus of this paper will highlight the problems experienced by Catholic couples in Manggarai Flores, Indonesia, as a result of the official view of Catholicism and the absence of state law regarding interfaith marriage.

\section{Methodology}

This study uses a literature approach and field studies. The literature study was carried out to obtain data related to the Catholic Church regulations regarding interfaith marriage. This section will explain the nature of marriage according to the view of the Catholic Church. Furthermore, it explains the various reasons for the prohibition of interfaith marriage and the various requirements for the validity of an interfaith marriage. The literature study also covers various research results on interfaith Marriage in Indonesia. All of this data is very important to form a more comprehensive frame of mind to guarantee the human rights and dignity of every human being relatively and intact in marriage.

The field study was directed to find data on problems experienced by Catholic couples who married people of different religions. The approach is qualitative, and data collection uses interviews. Respondents were determined purposively. Eight respondents are Catholics and have been married to partners from other religions (primarily Islam). The questions submitted to the respondents were open-ended, in which the respondents were given ample space to describe their experiences in the marriage. Most of the respondents have experienced divorce from their partners of other religions 


\subsection{Catholic Teaching on Interreligious Marriage}

In the teachings of Catholicism, Marriage is something sacred. Marriage is not only a personal fellowship between a man and a woman but also a means to know God better, trust Him more fully and love Him more deeply. Marriage is a sacrament that symbolizes the fellowship of love between God and His people. As a sacrament, marriage is a sign and means by which the faith is expressed and strengthened, worship is rendered to God, and the sanctification of humankind is affected (Article 840 of the Code of Canon Law). In marriage, husband and wife work together to realize the communion of life and love of God in all its aspects and dimensions: personal-human and spiritual-religious at the same time.

Consequently, marriage demands total surrender between husband and wife and presupposes an exclusive physical, affective and spiritual union. In marriage, there is the total union of the two brides. They are no longer two but one heart. Unity of heart is very close to faith. It is challenging to imagine total unity between husband and wife or to speak of a united heart if they do not share the same faith. On this basis, the Catholic Church leaders always want their people to choose a partner who is of the same faith because faith has a powerful influence on the inner and outer unity of husband and wife, children's education, and family welfare. Article 1086 of the Code of Canon Law states that the marriage between a baptized person (Christian) and a non-baptized (non-Christian) is invalid.

According to the Catholic Church view, there are three main reasons for the prohibition of interfaith and interreligious marriage. First, marriage between people of different religions or between those of different faiths will make it difficult for the parties to manifest their respective faiths. If they come from the same religion, it is easier for husbands and wives to pray and manifest their beliefs. On the other hand, if they are different, they have to consider the beliefs of the other party when they want to pray or carry out their faith beliefs. In some instances, these difficulties can threaten or endanger a person's faith. Second, interfaith and interfaith marriages make it difficult for children's education. One of the fundamental rights of children is the right to education.

Concerning interfaith and interfaith marriages, children will experience differences or dualism in fulfilling their education rights, especially faith education. On the one hand, they learn their mother's religion; meanwhile, they also experience a different education from their father. If this is not managed correctly, children will experience difficulties in developing their faith. Third, interfaith marriage does not represent the love fellowship between Yahweh and His people, between Christ and his Church (Lon, 2019a).

However, the prohibition on marrying a non-baptized person is not closed. In Article 1086 verse 2, the Church opens space for dispensation by the competent authorities to Catholics who wish to marry non-baptized persons. Dispensation is a relaxation of a merely ecclesiastical law in particular case for the reason that it is reasonable and just. Dispensation is a Church means to accommodate Catholics who genuinely love non-baptized people and are committed to marrying them. The giving of dispensation is not only a form of recognition of the reality of interfaith love for Catholics but especially as a form of recognition of the human rights of their people, especially the right to marry and choose a religion according to their conscience (Lon, 2019b).

In his Encyclical Amoris Laetitia (AL) No 248, Pope Francis invites the Catholic Church to pay special attention to the issue of love concerning religious beliefs. Pope said "Attention needs to be given to the persons who enter such marriages, not only in the period before the wedding. Unique challenges face couples and families in which one partner is Catholic, and the other is a non-believer. In such cases, bearing witness to the ability of the Gospel to immerse 
itself in these situations will make possible the upbringing of their children in the Christian faith".

The Pope emphasized that every pastoral activity is pursued while respecting the religion of the partner. Following the human rights of each person, the Catholic Church still respects those who are not Catholic in earnest. The Church continues to hope that they will receive the best attention and appreciation. The openness of the Church to religions has implications for her urging the Church to serve humanity to internal groups and all humanity. The Church must be a sign of salvation for all humanity. Likewise, everyone should experience the grace, care, love, and support of the Catholic Church.

\section{Result and Discussion}

Rozakis (Calvina \& Yusuf, 2012) notes that religious differences with partners in a marriage can cause many problems. In the Indonesian context, Ratno Lukito (S Wahyuni, 2019) has noted various difficulties in implementing interfaith marriages in Indonesia. This study found several problems faced by catholic couples who married non-Catholic (Moslems). The results of interviews with respondents indicate the following problems.

\section{The problem of double forms of Marriage celebration}

The celebration of marriage is carried out in two different religious ceremonies, namely in a Catholic manner and in a non-catholic manner. Consequently, the marriage vow is made twice. Ira, in her confession, told that her Marriage with Mohammad occurred before the KUA in Java, in Mohammad's religious community (Islam), and her community at the Catholic Church in Manggarai. The same story was told by Martinus (from Manggarai), who was married to Wati (from Malang). Martinus explained that the marriage before the KUA occurred because Wati had insisted on being responsible for the fetus in her womb. As a sign of responsibility, Martinus was willing to celebrate his marriage before the KUA, according to the wishes of the bride's family. At that time, Martinus converted to Islam and married as a Muslim. However, Martinus did not inform his parents in Manggarai because his motivation was to please and follow the wishes of Wati and her family.

After finishing his study, Martinus asked Wati to come to Manggarai Flores. In Manggarai, his parents urged them (Martinus and Wati) to marry in Catholic Church. Neither Wati nor Martinus dared to say that they were married in Islam. They just followed the will of his parents. They made their marriage vows in front of Catholic priests in an official Catholic ceremony. At that time, Wati was baptized into Catholicism before the marriage vows to marry as a Catholic. In short, Martinus and Wati carried out their Marriage vows twice in front of their respective religious leaders according to their religious customs.

The case of double forms of marriage celebration as above occurs mainly because each partner (husband and wife) wants to have a place and recognition from his/her respective religious communities. According to Horowitz (Calvina \& Yusuf, 2012), married couples of different religions often face adverse reactions and a lack of understanding from their extended family towards them. Wallerstein and Blakeslee (Fatimah et al., 2019) argue that one of the challenges experienced by couples of different religions is the emotional closeness to the family that has raised them. Each couple wants his/her marriage to be approved by his/her own family and community. This desire is originated in the powerful emotional attachment of each partner to his/her extended family and community. Such attachments are especially prominent in those 
with family identities that are in line with and united with their religious and cultural identities. According to some researchers (Lon \& Widyawati, 2019) (Widyawati, 2020) (Seul, 1999), religion has the most decisive influence on individuals' and groups' identity. In contrast, Naomi (Riley, 2013) sees the problem concerning the level of faith and religion of those who marry different religions.

Kadek W. Indrayanti et al. (Indrayanti, 2017) viewed mixed marriages of different religions as an indicator of religious openness and freedom. However, they also highlighted the vacuum of law as the root of various problems in interfaith marriages in Indonesia. The case of double forms of marriage celebration can also be interpreted as a result of the provisions of Article 2 of the Republic of Indonesia Law No.1 of 1974 concerning marriage, which states that marriage becomes valid if it is carried out following the procedures of one's respective religion. When they come from two different religions, their marriage is carried out in two different marriage rituals according to their respective religions. The ritual of marriage celebration before the KUA answers the legal requirements for Muslims, while the ritual of marriage celebration in the Church fulfills the legal requirements for Catholics. This interpretation occurs due to the vacuum of law or the absence of specific rules governing marriage between people of different religions in Law No. 1 of 1974 on marriage.

Fuller L. (Luban, 2001) notes the importance of a legal basis for the validity of legal action. The question is raised: How is the legal status of the two forms of marriage celebration? Can both of them exist as a legal basis for the validity of their marriage? In the case of double forms of the marriage celebration, the Catholic Church only recognizes one form of marriage celebration because the marriage consent made in marriage celebration cannot be withdrawn and is otherwise legally protected until proven otherwise (Articles $1057 \& 2$ and Article 1060 of the Code of Canon Law). Marriage is permanent, and therefore the consent of the marriage vows is done once and forever.

Thus, Martinus and Wati must determine one of the two forms of their marriage celebration to be recorded in religious and state documents. This determination is also related to the religious status of the bride and groom, namely Wati and Martinus. If Ira or Martinus officially becomes a Muslim, then marriage celebration before the KUA is valid and becomes the basis of their marriage. However, if Muhammad or Wati officially becomes Catholic, then Marriage in the Church becomes the basis for the validity of the marriage. However, if each of them still keeps his/her respective religions, then they must consider the rules of each religion.

In the Catholic view, mixed interfaith marriages performed before the KUA can become valid if there is a dispensation from the competent Church authority. There are two types of dispensation here. First, the dispensation to marry a person who is not a Catholic; second, the dispensation to be celebrated in non-catholic marriage ritual. If these two dispensations exist, then mixed interfaith marriages performed before the KUA are valid. However, if both or one of the dispensations do not exist, then the above marriage is invalid (Article 1086 and Article 1108 of the Code of Canon Law).

\section{The problem of children's religious education}

Many researchers such as Marcia J.E., Rosenbaum M. \& Rosenbaum S and Rozakis (Calvina \& Yusuf, 2012) highlight the problem of choosing religion in children of different religious partners. Thomas and Emiszanah argue that most children do not receive adequate religious education in interfaith marriages. If there is religious education, it causes a conflict of values in children (Calvina \& Yusuf, 2012). This study found two models of religious education in mixed marriages with different religions. First, all children in the family were educated with two different religious values. All children attended religious and moral education of their father 
and mother. Maria stated that she educated children in a Catholic manner, and her husband educated children in Islam.

On Sundays, the children went to Church, and on Fridays, they were brought to the mosque. Sometimes their children prayed according to Islamic teachings; sometimes, they prayed according to Catholic teachings. Dewi and Hendrik said almost the same thing. According to him, when living in Java in an Islamic environment, children's education predominantly followed Islam. However, when they returned to Manggarai, children's education was more dominant in Catholic religious education. Second, children's education was divided into two groups: the father's religious group and the mother's religious group. Some children were educated in a Catholic manner to follow a Catholic spouse, and some children were educated non-Catholics to follow a non-Catholic spouse. This case was experienced by the couple Peter and Miriam. Boys are educated according to their mother's religion, while girls are according to the religion of their father.

One of the goals of religious education is to develop children's abilities to believe and fear God Almighty and have good moral character according to religious norms or social norms (Article 1 of the Indonesian National Education System Law, 2003). Religious education is carried out consciously, systematically, and pragmatically to help and direct children to follow and live according to certain religious teachings. In the first model above, children are given the space to choose their religion after attending the two religions that are different from their parents. This model is, of course, somewhat in line with the demands of children's rights. However, this model presupposes adequate and inclusive religious education not to cause children to experience inner conflicts with the two religious values they receive.

Elvina and Elvi (Calvina \& Yusuf, 2012) noted the confusion in choosing religion among children of partners of different religions. Children often question the different religious teachings of their parents, and this often creates conflicts in children. According to Elmirzanah and Juhaz (Calvina \& Yusuf, 2012), conflict is a reality that must be faced in a situation of diversity, including religious diversity. Conflicts like this will become even more vital when children enter adolescence. In adolescence, children want to have their religious identity; however, children of different religions often have doubts about religious concepts and beliefs received from their parents. This doubt refers to as religious doubt (Christanto et al., 2018). According to Surbakti (Surbakti, 2009), these doubts often lead to conflicts within children and even make children pessimistic about religious diversity (Calvina \& Yusuf, 2012).

In the second model above, children's religious education aims to direct children to follow and live according to the religion of their parents, whether the religion of the father or the religion of the mother. Such education occurs mainly because it considers the interests of parents and the community. Religious education for children is divided to fulfill the rights of each partner and not primarily to fulfill the child's right to religion. Here education has not been seen as a child's effort to express him/herself and realize his/her talents or potentials. Education like this will give children a photocopy of their parents (Lon \& Widyawati, 2017)

Furthermore, the impact of education very much depends on the level of inclusiveness of religious education. Inclusive religious education creates a paradigm of religious life that is open to people of other religions. Seymour and Tabita (Rumahuru, 2019) mention three types of religious education and teaching: religious education and teaching in the wall, at the wall, and beyond wall. Religious education in the wall is exclusive and closed to the existence of other religions. Religious education at the wall considers the plurality of religious understanding, while religious education beyond the wall also builds solidarity between children of different religions and beliefs. 
Ideally, religious education allows children to provide space for static dialogical relationships and make children of different religions work together to build peace and justice while respecting differences.

\section{Problems of illegal Marriage and exclusion from religious communities}

In her confession, Ina, who was "married" to Ahmad from Kalimantan, said that her marriage was not accepted and recognized by her family and religious leaders. She said: "At that time, I was very depressed. On the one hand, my relationship with Ahmad went too far and caused me pregnant. On the other hand, each of our parents wanted us to maintain our respective religions in marriage. In this situation, Ahmad and I chose to live together as husband and wife without a religious form of celebration. Yes, just like " kumbul kebo ". Since then, I have not been closing to my parent's community, friends, and neighbors who are of the same faith and even to the Church anymore. I felt that there was no place for me in the Church. In the end, I was forced to have a Marriage according to Ahmad's religion, namely Muslim. I have to convert to Islam, a new life that was very foreign to me. Even though I myself do not know how to pray in Islam. Every day I still pray in catholic, but secretly ".

Couples with different religions often experience difficulties in carrying out legal marriages due to religious issues. This difficulty cannot be resolved because Law No. 1 of 1974 on marriage does not explicitly state Interfaith Marriage in its articles. Article 57 only talks about mixed nationality marriages. So when article 2 emphasizes that legal marriages must be carried out according to the laws of religion and beliefs of each, implicitly this rule prohibits mixed interfaith marriages (Sri Wahyuni, 2016).

This prohibition is, of course contrary to Article 29 of the 1945 Constitution, which guarantees the right of every citizen to embrace his religion and worship according to his religion and belief. This right should not be restricted, including when a person is married, because everyone has the right to form a family and continue their offspring through a legal marriage and free will (Article 10 (1) of Law No. 39 of 1999 on Human Rights. Indeed, Law No. 23 of 2006 Concerning Population Administration, Article 35 letter a provides opportunities for those who are going to marry interfaith marriages, but the effect is not significant.

Furthermore, the legal vacuum causes interfaith marriages not to receive legal protection, and therefore, husband and wife couples suffer injustice. The above case shows how a husband and wife of different religions smuggle the law so that their marriage gets social and juridical recognition. This "law smuggling" is in the form of changing religions according to the religion of the partner for a while or being forced to follow the religion of the partner even though it is against their conscience (Setyowati, 2015). In line with this case, Rambo and Stark (Rani Dwisaptini, 2008) argue that the inner pressure that a person experiences socially can cause him to change religions. As a result, the Catholic couple in the marriage is not allowed to receive spiritual services from Catholic Church officials, such as receiving or receiving holy communion in the celebration of the eucharist (Article 915 of the Code of Canon Law). They are further classified as sinners (Lon, 2019b) (Widyawati, 2020).

\section{The problem of Marriage Failure and divorce}

John told me that his Marriage to Melan was forced to end in divorce. This happened because differences, squabbles, and fights marred his married life. Even small matters become big. For example, coming home late from work could become a big fight. After a closer examination, it turned out that this was due to religious differences between the two. They never prayed together. On Friday, John went to the mosque, Melan went to the mall. 
Conversely, when Melan went to Church on Sundays, John went to a tourist spot. When they had a meal together, they prayed according to their respective beliefs. At first, they tried to understand each other. However, after two years, the suspicion and sensitivity between them grew stronger. Over time, their family life was more dominated by differences of opinion, which ended in quarrels and arguments. Over time, their differences became a great conflict, threatening the integrity of the family. Approximately four years after their marriage, they finally decided to divorce.

According to Judith Wallerstein (Fatimah et al., 2019), one of the challenges experienced by couples of different religions is the emotional closeness to the family that has raised them. Therefore, to smooth their married life, one of them must be willing to let go of the emotion of closeness and kinship. If not, then it can interfere and damage the long-term relationship of the family life. When they marry a couple of different religions, they will experience guilt for leaving and fighting their family.

Naomi (Riley, 2013) argues that the problems that arise in couples of different religions are rooted in the level of their religious life. In her survey of 2450 Americans who have interfaith marriages, Naomi found that $58 \%$ of those who have interfaith marriages are between the ages of 26-36, and they tend to be less serious about their religious life. Therefore, they tend to marry without thinking about the implications of their different beliefs. They do not have many discussions about the beliefs that will be taught to their children later. This is especially crucial for couples who want their children to follow their faith. No wonder their child is not active in religious activities. Some of them even left religion. Furthermore, Naomi said that married couples with different religions have a divorce risk three times higher than couples with the same religious belief. There is a fundamental dispute that makes this marriage difficult.

Meanwhile, Gudykunst \& Kim (Syam et al., 2017) argue that the harmony and integrity of marriages of people of different religions are strongly influenced by the interpersonal communication skills of the two partners. The ability to process anxiety, the ability to empathize, the ability to adapt behavior, the ability to make accurate explanations and predictions will make it easier for couples of different religions to understand and support each other. Communication skills help create an environment and culture in a community or family of different religions (Martin, N. Judith dan Nakayama, 2004). The ability to communicate between individuals in families of different religions will encourage the expression of feelings of equality and difference openly, wisely, and precisely. According to De Vito (DeVito, 1991), effective interpersonal communication is characterized by openness, empathy, positive feelings, support, and balance.

\section{Conclusion}

Marriage between people of different religions is an unavoidable reality in Indonesia. Nevertheless, such marriage is not an easy and pleasant choice. Married couples of different religions face many difficulties and challenges. This research shows that married couples of different religions must carry out their marriage vows twice in front of their respective religious leaders to have a place and recognition from their respective religious community. Even though the legal status of their marriage is also questionable. In many cases, interfaith marriages have no legal, social, and religious protections. Their children experience confusion in choosing religion or even have no right to religious education. Furthermore, couples of different religions experience difficulties in realizing family harmony and happiness and maintaining the integrity 
of their marriage. The study concludes that interreligious marriages presuppose legal, social and religious protections. Meanwhile, couples with different religions are required to have a good quality of inclusive religious mindset and communicate effectively and efficiently with each other. This study recommends revising the Marriage Law No. 1/1974 and adopting a new law that is friendly to interreligious/interfaith marriage.

\section{References}

[1] Aini, N. (2008). Inter-Religious Marriage from Socio-Historical Islamic Perspectives. Brigham Young University Law Review - 669, 2008(3), 669-705.

[2] Calvina, \& Yusuf, dan E. A. (2012). Konflik Pemilihan Agama Pada Remaja Dari Perkawinan Beda Agama (Conflict of Choosing Religion from Adolescent of Interfaith Marriage. PREDICARA.

[3] Christanto, F. A., Susilo, T. D., \& Windrawanto, Y. (2018). Effect of self-confidence on high school student's social adjustment. Jurnal Pendidikan Dan Pengajaran, 51(3), 110-114.

[4] DeVito, J. (1991). The Interpersonal Communication Course. Basic Communication Course Annual, 3(1), 1-20.

[5] Fatimah, I. P., Amirudin, A., \& Lathifah, A. (2019). Agama dan Pernikahan Pasangan Beda Agama di Sendangmulyo Semarang. Endogami: Jurnal Ilmiah Kajian Antropologi, 3(1), 1. https://doi.org/10.14710/endogami.3.1.1-8

[6] Gledys Patrisia Sepan. (2015). Tinjauan Hukum Terhadap Perkawinan Beda Agama Menurut Hukum Kanonik Dan Undang-Undang Nomor 1 Tahun. Lex et Societatis.

[7] Husain Insawan. (2008). Perkawinan Beda Agama: Menakar Nilai-nilai Keadilan Kompilasi Hukum Islam: Resensi karya M. Karsayuda. Al- ‘ADL Jurnal Hukum Dan Pranata Sosial Islam,

[8] Indrayanti, K. (2017). Juridical Implications of the Legal Norm Void of Interfaith Marriages in Indonesia. Brawijaya Law Journal, 4(1), 129-143. https://doi.org/10.21776/ub.blj.2017.004.01.07

[9] Lon, Y. S. (2019a). Hukum Perkawinan Sakramental Dalam Gereja Katolik. https://books.google.co.id/books?hl=en\&lr=\&id=o_8FEAAAQBAJ\&oi=fnd\&pg=PT5\&dq=+huk um+perkawinan+sakramental+dalam+gereja + katolik\&ots=aCGMy8cjaJ\&sig=AQDwWyf3qytob eyVSc6kwWu7VPw\&redir_esc $=\mathrm{y} \# \mathrm{v}=$ onepage $\& \mathrm{q}=$ hukum perkawinan sakramental dalam gereja katolik\&f=false

[10] Lon, Y. S. (2019b). The Legality of Marriage According to Customary, Religion and State Laws: Impacts on Married Couples and Children in Manggarai. Jurnal Dinamika Hukum, 19(2), 302. https://doi.org/10.20884/1.jdh.2019.19.2.2429

[11] Lon, Y. S., \& Widyawati, F. (2017). Lingkaran Kekerasan terhadap Anak dalam Masyarakat Manggarai. Jurnal Pendidikan Dan Kebudayaan Missio, 10, 12-20.

[12] Lon, Y. S., \& Widyawati, F. (2019). Food and local social harmony: Pork, communal dining, and muslim-Christian relations in Flores, Indonesia. Studia Islamika, 26(3), 445-474. https://doi.org/10.36712/sdi.v26i3.9917

[13] Luban, D. (2001). Natural law as professional ethics: A reading of Fuller. Social Philosophy and Policy, 18(1), 176-205. https://doi.org/10.1017/S0265052501181070

[14] Makalew, M. (2013). Akibat Hukum Dari Perkawinan Beda Agama di Indonesia. Lex Privatum, $1(2), 131-144$.

[15] Martin, N. Judith dan Nakayama, T. K. (2004). COMMUNICATION.

[16] Munir. (2011). "Perkawinan Beda Agama dalam Perspektif Agama-agama".

[17] Pujiasih, A. (2008). Pernikahan beda agama menurut islam dan katolik.

[18] Rani Dwisaptini, J. L. S. (2008). Konversi Agama Dalam Kehidupan Pernikahan. Humaniora, 20(3), 327-339.

[19] Riley, N. S. (2013). Til Faith Do Us Part: How Interfaith Marriage is Transforming America. Oxford University Press.

[20] Rumahuru, Y. Z. (2019). Mengembangkan Pendidikan Agama Inklusif sebagai Solusi Pengelolaan Keragaman di Indonesia. Jurnal Teruna Bhakti, 1(1), 59. https://doi.org/10.47131/jtb.v1i1.13 
[21] Setyowati. (2015). 2015. 8(4), 7-10.

[22] Seul, J. R. (1999). "Ours is the way of God": Religion, identity, and intergroup conflict. Journal of Peace Research, 36(5), 553-569. https://doi.org/10.1177/0022343399036005004

[23] Supriadi. (2020). Tinjauan Hukum terhadap Perkawinan Beda Agama Yang Dilaksanakan di Luar Negeri, AL-SYAKYSIYYAH: Jurnal Hukum Keluarga Islam Dan Kemanusiaan.

[24] Surbakti, M. (2009). Pemilihan Agama Pada Anak Dari Perkawinan Beda Agama.

[25] Syam, N. K., Mulyana, D., Rachmiatie, A., \& ... (2017). Adaptasi perkawinan lintas agama. Jurnal Lentera: Kajian ..., 3(March). https://www.neliti.com/publications/177275/adaptasi-perkawinanlintas-agama

[26] Wahyuni, S. (2019). Running Away from Authority to Gain Recognition (The Case of Indonesian Interfaith Marriage Overseas). AIUA Journal of Islamic Education. http://aiuajournalofislamiceducation.net/index.php/home/article/view/30

[27] Wahyuni, Sri. (2010). "Kontroversi Perkawinan Beda Agama di Indonesia”. Jurnal Hukum Islam (JHI),

[28] Wahyuni, Sri. (2016). Nikah Beda Agama: Kenapa ke Luar Negeri? - Dr. Sri Wahyuni, M.Ag., M.Hum. $\quad$ - Google Buku. https://books.google.co.id/books?hl=id\&lr=\&id=uZ3fDQAAQBAJ\&oi=fnd\&pg=PA1\&dq=perm asalahan+agama+islam+dalam+perkawinan\&ots=abiM5me7J0\&sig=UJv8PB6cdgWefH3Y7lalo $\mathrm{QQk7Ss \& redir}$ esc $=\mathrm{y} \# \mathrm{v}=$ onepage $\& \mathrm{q}=$ permasalahan agama islam dalam perkawinan $\& \mathrm{f}=\mathrm{false}$

[29] Wahyuni, Sri. (2018). Kontroversi Perkawinan Beda Agama di Indonesia. Al-Risalah, 14(02), 293. https://doi.org/10.30631/al-risalah.v14i02.452

[30] Widyawati, F. (2020). When Love and Faith Collide Women's Conversion to Husband' s Religion in Flores. 14(02), 335-358. 